\title{
Prevalence of cardiometabolic risk factors in patients with hypertension and subclinical hypothyroidism
}

\author{
A. O. Radchenko ${ }^{D} * B, C, D, 0$. V. Kolesnikova ${ }^{A, E, F}$ \\ GI “L. T. Malaya Therapy National Institute of the National Academy of Medical Sciences of Ukraine”, Kharkiv
}

A - research concept and design; B - collection and/or assembly of data; C - data analysis and interpretation; D - writing the article; $\mathrm{E}$ - critical revision of the article; $\mathrm{F}$ - final approval of the article

Key words: cardiometabolic risk factors, metabolic syndrome, lipid profile, hypertension, subclinical hypothyroidism.

\section{Zaporozhye} medical journal 2021; 23 (6), 800-805

*E-mail: anastasha.radchenko@ gmail.com
It is known that the presence of overt hypothyroidism carries additional risks of developing cardiovascular diseases due to impaired lipid and carbohydrate metabolism. But whether subclinical hypothyroidism ( $\mathrm{SH}$ ) has the same negative impact is still controversial. The assessment of its role is especially important in patients with existing arterial hypertension (AH) in the early stages of the disease in order to prevent future complications.

The aim of this work is to identify and assess the prevalence of early cardiometabolic risk factors in patients with AH combined with SH.

Materials and methods. 66 patients ( $55.4 \%$ women) aged from 25 to 59 years with a median age of 51.1 years were included in the study during 2019-2020 years. All the patients were divided into 3 groups, randomized by age and sex: group $1(n=21)-$ volunteers without $\mathrm{AH}$ and $\mathrm{SH}$; group $2(\mathrm{n}=25)$ - euthyroid patients with stage 1-2 grade 1-2 AH and low-to-moderate cardiovascular risk (CVR); group $3(n=20)$ - patients with stage 1-2 grade 1-2 AH and low-to-moderate CVR in combination with SH. Blood pressure was measured, anthropometric data were assessed, glucose levels and lipid profile indicators were determined in all patients.

Results. Comparative characteristics of the groups showed a rise in the frequency of detecting increased waist circumference and the waist-to-hip ratio, obesity, metabolic syndrome, its individual components and lipid profile disorders, especially the levels of total cholesterol and high-density lipoprotein cholesterol in patients with SH even in the early stages of AH and CVR of low gradations. However, dyslipidemias in general and hypertriglyceridemia in particular were more common in euthyroid hypertensive patients compared to patients with $\mathrm{AH}$ and concomitant $\mathrm{SH}$.

There was also a tendency towards an increase in gynoid obesity and a worsening of the lipid and carbohydrate profile disorders in $\mathrm{SH}$ patients in comparison to euthyroid patients with $\mathrm{AH}$, although the differences were not statistically significant.

Conclusions. Evaluation of cardiometabolic risk factors revealed the increase in severity of female obesity and worsening of abnormalities in lipid and carbohydrate profiles with the SH development in patients even in the early stages of AH and low-CVR, that additionally increases the risk of cardiovascular complications.
Ключові слова: кардіометаболічні фактори ризику, метаболічний синаром, міпідний профіль, артеріальна гіпертензія, субклінічний гіпотиреоз.

Запорізький медичний журнал. 2021. T. 23, № 6(129). C. $800-805$

\section{Поширеність кардіометаболічних факторів ризику в пацієнтів з артеріальною гіпертензією та субклінічним гіпотиреозом}

\section{А. О. Радченко, О. В. Колеснікова}

Відомо, що наявність маніфестного гіпотиреозу спричиняє додаткові ризики для розвитку серцево-судинних захворювань внаслідок порушення ліпідного й вуглеводного обміну. Але питання про те, чи має субклінічний гіпотиреоз (СГ) такий самий негативний вплив, залишається суперечливим.

Оцінювання його ролі особливо важливе в пацієнтів з артеріальною гіпертензією (АГ) на ранніх стадіях захворювання для запобігання майбутнім ускладненням.

Мета роботи - виявити та оцінити поширеність ранніх кардіометаболічних фракторів ризику у пацієнтів з АГ у поєднанні з СГ.

Матеріали та методи. У 2019-2020рр. у дослідження залучили 66 пацієнтів (55,4 \% жінок) віком 25-59 років (медіана51,1 року). Сформували 3 групи, рандомізовані за віком і статтю: група $1(n=21)$ - група добровольців без АГ і СГ; група 2 ( $n=25)$ - еутиреоїдні пацієнти з АГ 1-2 стадії, 1-2 ступеня та низьким/помірним кардіоваскулярним ризиком (КВР); група 3 ( $n=20)$ - хворі на АГ 1-2 стадії, 1-2 ступеня з низьким/середнім КВР у поєднанні з СГ. Усім обстеженим виміряли артеріальний тиск, оцінили антропометричні дані, визначили рівень глюкози, показники ліпідного профілю.

Результати. Порівняльна характеристика груп показала збільшення частоти виявлення збільшеного обводу талії та співвідношення обводу талії до обводу стегон, ожиріння, метаболічного синдрому, окремих його компонентів і порушень ліпідного профілю, особливо рівнів загального холестерину та холестерину ліпопротеїнів високої щільності у пацієнтів 3 появою СГ навіть на ранніх стадіях АГ і КВР низьких градацій. Однак дисліпідемії в цілому та гіпертригліцеридемія зокрема були поширенішими в еутиреоїдних пацієнтів з АГ порівняно з хворими на АГ із супутнім СГ.

Виявили тенденцію до посилення гіноїдного типу ожиріння і поглиблення порушень ліпідного та вуглеводного профілів у пацієнтів із приєднанням СГ порівняно з еутиреоїдними хворими на АГ, хоча відмінності не були статистично значущими.

Висновки. Оцінювання кардіометаболічних факторів ризику показало збільшення вираженості ожиріння за жіночим типом і поглиблення порушень у ліпідному та вуглеводному профілях у пацієнтів навіть на ранніх стадіях АГ і КВР низьких ступенів із появою СГ, що додатково збільшує ризик розвитку серцево-судинних ускладнень. 


\section{Распространённость кардиометаболических факторов риска у пациентов с артериальной гипертензией и субклиническим гипотиреозом}

\section{А. О. Радченко, Е. В. Колесникова}

Известно, что наличие манифестного гипотиреоза несет дополнительные риски развития сердечно-сосудистых заболеваний из-за нарушения липидного и углеводного обмена. Но вопрос о том, оказывает ли субклинический гипотиреоз (СГ) такое же негативное влияние, остается спорным. Оценка его роли особенно важна у пациентов с артериальной гипертензией (АГ) на ранних стадиях заболевания для предупреждения будущих осложнений.

Цель работы - установить и оценить распространенность ранних кардиометаболических факторов риска у пациентов с АГ в сочетании с СГ.

Материалы и методы. В 2019-2020 гг. в исследование включили 66 пациентов (55,4 \% женщин) в возрасте 25-59 лет (медиана - 51,1 года). Сформировали 3 группы, рандомизированные по возрасту и полу: группа $1(\mathrm{n}=21)$ - группа добровольцев без АГ и СГ; группа 2 ( $n=25)$ - эутиреоидные пациенты с АГ 1-2 стадии, 1-2 степени и низким/умеренным кардиоваскулярным риском (КВР); группа $3(n=20)$ - больные АГ 1-2 стадии, 1-2 степени с низким/средним КВР в сочетании с СГ. Всем обследованным измерили артериальное давление, оценили антропометрические данные, определили уровень глюкозы, показатели липидного профиля.

Результаты. Сравнительная характеристика групп показала увеличение частоты выявления повышенного объема талии и соотношения объема талии к объему бедер, ожирения, метаболического синдрома, отдельных его компонентов и нарушений липидного профиля, особенно уровней общего холестерина и холестерина липопротеинов высокой плотности у пациентов с появлением СГ даже на ранних стадиях АГ и КВР низких градаций. Однако дислипидемии в целом и гипертриглицеридемия в частности более распространены у эутиреоидных пациентов с АГ по сравнению с больными АГ с сопутствующим СГ.

Отмечена тенденция к усилению гиноидного типа ожирения и углубление нарушений липидного и углеводного профиля у пациентов с присоединением СГ в сравнении с эутиреоидными больными АГ, хотя различия не были статистически значимыми.

Выводы. Оценка кардиометаболических фракторов риска показала увеличение выраженности ожирения по женскому типу и углубление нарушений в липидном и углеводном профилях у пациентов даже на ранних стадиях АГ и КВР низких степеней с появлением СГ, что дополнительно увеличивает риск развития сердечно-сосудистых осложнений.

Arterial hypertension $(\mathrm{AH})$ is diagnosed in more than $40 \%$ of the world population and this number is constantly growing, especially among the population of Central and Eastern Europe [1]. One of the negative consequences of this disease is disability. The average number of total years of life lost and disability adjusted life years (DALYs) due to disability and premature mortality caused by cardiovascular disease (CVD) was 10.000 per 100.000 Ukrainian population in 2017 [2]. The number of DALYs due to AH increased by $31 \%$ over the period 2007 to 2017 [3]. At the same time, the prevalence of hypothyroidism in Ukraine has also been growing in recent years. Subclinical hypothyroidism (SH) is a pathological condition that precedes the development of overt (manifest) hypothyroidism. It is characterized by an increase in thyroid-stimulating hormone (TSH) levels above normal with normal laboratory values of thyroxine and triiodothyronine. The prevalence of $\mathrm{SH}$ is about $10 \%$ among the population. The frequency of $\mathrm{AH}$ detection in patients with $\mathrm{SH}$ is quite high, which indicates the common links in the pathogenesis of both diseases. In the South Indian Population Study, $\mathrm{AH}$ was found in $24.6 \%$ of patients with $\mathrm{SH}$, and E. Piantanida et al. (2016) found that masked $\mathrm{AH}$ was revealed in $26.3 \%$ of SH patients [4,5]. The negative impact of overt hypothyroidism on CVD has been proven by a large number of studies. For instance, it is known that increase in TSH is a statistically significant predictor of lipid and carbohydrate metabolism disorders, and decrease in thyroid function leads to the development of dyslipidemia, insulin resistance, obesity, metabolic syndrome (MS), hyperuricemia [6]. Lipid and carbohydrate metabolism disorders have also been found to be the most important cardiovascular risk (CVR) factors resulting in the develop- ment of age-associated diseases [7]. An assessment of subclinical thyroid dysfunction has been made possible only recently owing to new highly sensitive methods of laboratory diagnosis. Thus, current data on the impact of $\mathrm{SH}$ on the progression of CVD, namely $\mathrm{AH}$, are limited and quite contradictory $[8,9]$.

Diagnostic suspicion of $\mathrm{SH}$ in the population, especially among non-elderly patients without severe comorbid pathologies, is often absent in the routine practice of primary and secondary care physicians. Therefore, it is interesting to study the influence of SH on the CVR factors occurrence in patients with $\mathrm{AH}$ in the early stages of the disease. Existing studies suggest that elevated levels of TSH and low levels of free thyroxine, even within baseline ranges, are associated with a higher risk of carbohydrate metabolism disorders, the development of type 2 diabetes mellitus (DM) and an increased risk of $\mathrm{AH}[10,11]$. The highest percentile of highly sensitive TSH among patients in Taiwan with a significantly increased risk of overweight, central obesity, high blood pressure, dyslipidemia, and MS is a case in point [12]. The occurrence and severity of many CVR factors, especially their combination, in patients with a combined course of $\mathrm{AH}$ and $\mathrm{SH}$ can cause more severe disorders and accelerate the progression of both diseases. Therefore, it is important to correctly assess the impact of SH on the CVR to optimize preventive measures for $\mathrm{AH}$ patients.

\section{Aim}

The aim of this study was to identify and evaluate the prevalence of early cardiometabolic risk factors in patients with $\mathrm{AH}$ combined with $\mathrm{SH}$.
Ключевые слова: кардиометабомические факторы риска, метаболический синАрОМ, мипиАный профиль, артериальная гипертензия, субклинический гипотиреоз.

Запорожский медицинский журнал. 2021. T. 23, № 6(129). C. $800-805$ 


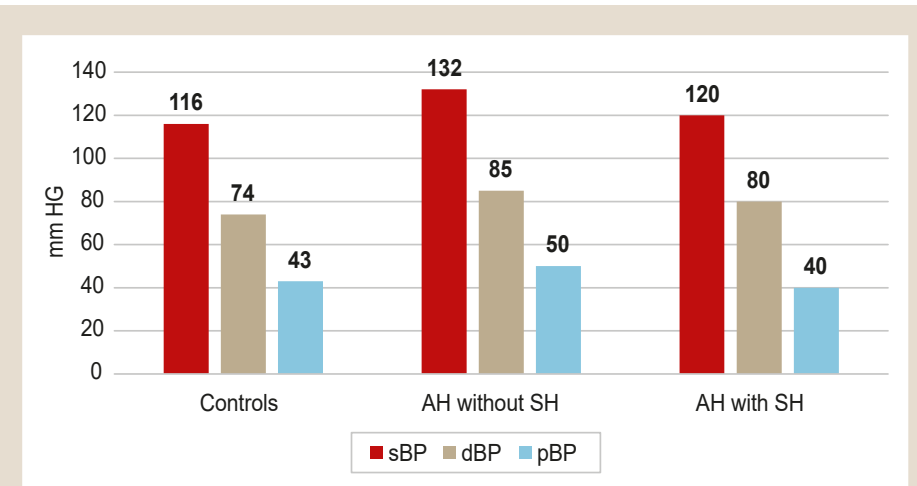

Fig. 1. Comparative characteristics of the mean blood pressure values in the examined patients

Table 1. Anthropometric characteristics of the studied patients

\begin{tabular}{|c|c|c|c|c|}
\hline $\begin{array}{l}\text { Indicators, } \\
\text { units }\end{array}$ & $\begin{array}{l}\text { Controls } \\
(n=21)\end{array}$ & $\begin{array}{l}\text { AH without SH } \\
(n=25)\end{array}$ & $\begin{array}{l}\text { AH with SH } \\
(n=20)\end{array}$ & $\begin{array}{l}\mathbf{P}^{1} \\
\mathbf{P}^{2} \\
\mathbf{P}^{3}\end{array}$ \\
\hline Weight, kg & $66.5[60.0 ; 82.8]$ & $88.0[75.8 ; 95.5]$ & $78.0[71.0 ; 88.0]$ & $\begin{array}{l}0.004 \\
0.053 \\
0.284\end{array}$ \\
\hline BMI, $\mathrm{kg} / \mathrm{m}^{2}$ & $23.8[21.5 ; 27.2]$ & $27.3[25.4 ; 28.6]$ & $27.1[26.4 ; 29.8]$ & $\begin{array}{l}0.022 \\
0.005 \\
0.423\end{array}$ \\
\hline WC, m & $0.805[0.755 ; 0.921]$ & $0.938[0.798 ; 1.013]$ & $0.930[0.920 ; 1.030]$ & $\begin{array}{l}0.008 \\
0.003 \\
0.878\end{array}$ \\
\hline $\mathrm{HC}, \mathrm{m}$ & $0.985[0.958 ; 1.053]$ & $1.010[0.923 ; 1.063]$ & $1.050[1.020 ; 1.100]$ & $\begin{array}{l}0.541 \\
0.004 \\
0.027\end{array}$ \\
\hline $\mathrm{WC} / \mathrm{HC}$ & $0.80[0.77 ; 0.90]$ & $0.92[0.88 ; 0.95]$ & $0.88[0.87 ; 0.90]$ & $\begin{array}{l}0.003 \\
0.035 \\
0.125\end{array}$ \\
\hline
\end{tabular}

$\mathrm{P}^{1}$ : controls vs $\mathrm{AH}$ without $\mathrm{SH}$; $\mathrm{P}^{2}$ : controls vs $\mathrm{AH}$ with $\mathrm{SH} ; \mathrm{P}^{3}$ : $\mathrm{AH}$ without $\mathrm{SH}$ vs $\mathrm{AH}$ with $\mathrm{SH}$.

\section{Materials and methods}

The study included 66 patients with low-to-moderate CVR and mean age of 51.1 [41.7; 56.2] years who underwent outpatient or inpatient treatment at the GI "L. T. Malaya Therapy National Institute of the National Academy of Medical Sciences of Ukraine" (L. T. Malaya NIT NAMSU) from 2019 to 2020 and signed an informed consent to participate in the study. Among the subjects, women accounted for $55.4 \%$ $(n=41)$. The research protocol was approved at a meeting of the Ethics Commission of the L. T. Malaya NIT NAMSU. The methods of examination used in this work correspond to the principles of the Helsinki Declaration on the Ethical Principles of Medical Research Relating to Human Subjects and its Revisions (2008), the Council of Europe Convention on Human Rights and Biomedicine (2007) and recommendations of the Bioethics Committee at the Presidium of the National Academy of Medical Sciences of Ukraine (2002).

All the patients were divided into 3 groups, randomized by age and sex: group $1-21$ volunteers without $\mathrm{AH}$ and $\mathrm{SH}$ (hereinafter - controls); group 2 - 25 euthyroid patients with stage 1-2 grade 1-2 AH and low-to-moderate CVR (hereinafter $-\mathrm{AH}$ without $\mathrm{SH}$ ) and with signs of autoimmune thyroiditis (AIT); group 3-20 patients with stage 1-2 grade 1-2 AH and low-to-moderate CVR combined with $\mathrm{SH}$ and with signs of AIT (hereinafter - AH with $\mathrm{SH}$ ). The diagnosis of $\mathrm{AH}$ was made on the basis of 2018 European Society of Hypertension/European Society of Cardiology Guidelines for the management of $\mathrm{AH}$. All the patients received standard therapy for $\mathrm{AH}$. The diagnosis of AIT was verified by ultrasound examination of the thyroid gland, determination of thyroperoxidase antibody (ATO-Ab) and thyroid function in all patients. The presence of $\mathrm{SH}$ in patients was assessed according to the 2013 European Thyroid Association clinical guidelines for $\mathrm{SH}$.

The inclusion criteria were age $25-59$ years, stage 1-2 grade 1-2 $\mathrm{AH}$.

Exclusion criteria were: the presence of acute or exacerbation of chronic inflammatory diseases at the beginning of the study; cerebrovascular diseases; heart disease (a history of coronary heart disease, myocardial infarction, coronary revascularization, chronic heart failure stage IIB and III); overt hypothyroidism; severe renal and hepatic failure; oncological diseases; rheumatic diseases; allergic, viral and autoimmune diseases; pregnancy; patient refusal to participate in the study.

All the patients underwent clinical examination that included blood pressure (BP) and anthropometric measurements (height, weight, waist (WC) and hip circumferences $(\mathrm{HC})$, body mass index (BMI), WC to $\mathrm{HC}$ ratio. The gynoid morphotype (low WC to HC ratio: for women <0.8; for men $<0.9$ ) in patients was evaluated as one of the protective factors against cardiometabolic risks. Lipid profile (total cholesterol (TC); triglycerides (TG); very low-density lipoprotein cholesterol (VLDL-C); high-density lipoprotein cholesterol (HDL-C); atherogenic coefficient (AC); low-density lipoprotein cholesterol (LDL-C)), carbohydrate profile (fasting glucose level; homeostasis model assessment of insulin resistance, HOMA-IR) were also determined. The presence of MS and its components as cardiometabolic risk factors were determined according to the criteria of the International Diabetes Federation (IDF) (2006).

Statistical processing of the results was performed using the application package Statistica (GRDKR-JFFPDB34B-3GBV9-QTTHJ), with the serial number X12-53766. Since most of the variables were not normally distributed, the results were presented as the median (Me) and interquartile ranges - 25 (Q1) and 75 (Q3) percentiles - Me (Q1; Q3). The non-parametric Mann-Whitney $U$ test was used to compare indicators between groups. Equality of group variances was checked using Fisher's exact (one-sided) test in four-field tables. Statistically significant differences were determined at a level of $\mathrm{P}<0.05$.

\section{Results}

An objective examination showed that patients in group 3 had better systolic BP $(\mathrm{sBP})$ control $(\mathrm{P}=0.013)$ compared with group 2, as well as lower levels of diastolic BP (dBP), but the results were not statistically significant (Fig. 1). In our study, BP in patients with $\mathrm{AH}$ and $\mathrm{SH}$ was even lower compared to that in patients without $\mathrm{SH}$. It is still unclear whether mild thyroid dysfunction affects $B P$, that requires further study using the results of daily BP monitoring.

According to the results of anthropometric measurements (Table 1), the highest mean values of weight, BMl, $\mathrm{BP}$ and $\mathrm{WC}$ to $\mathrm{HC}$ ratio were in group 2 patients. In patients with $\mathrm{AH}$ and $\mathrm{SH}$, all anthropometric parameters, except for weight, were statistically higher than those in controls, but not as much as the corresponding values in group 2 . 


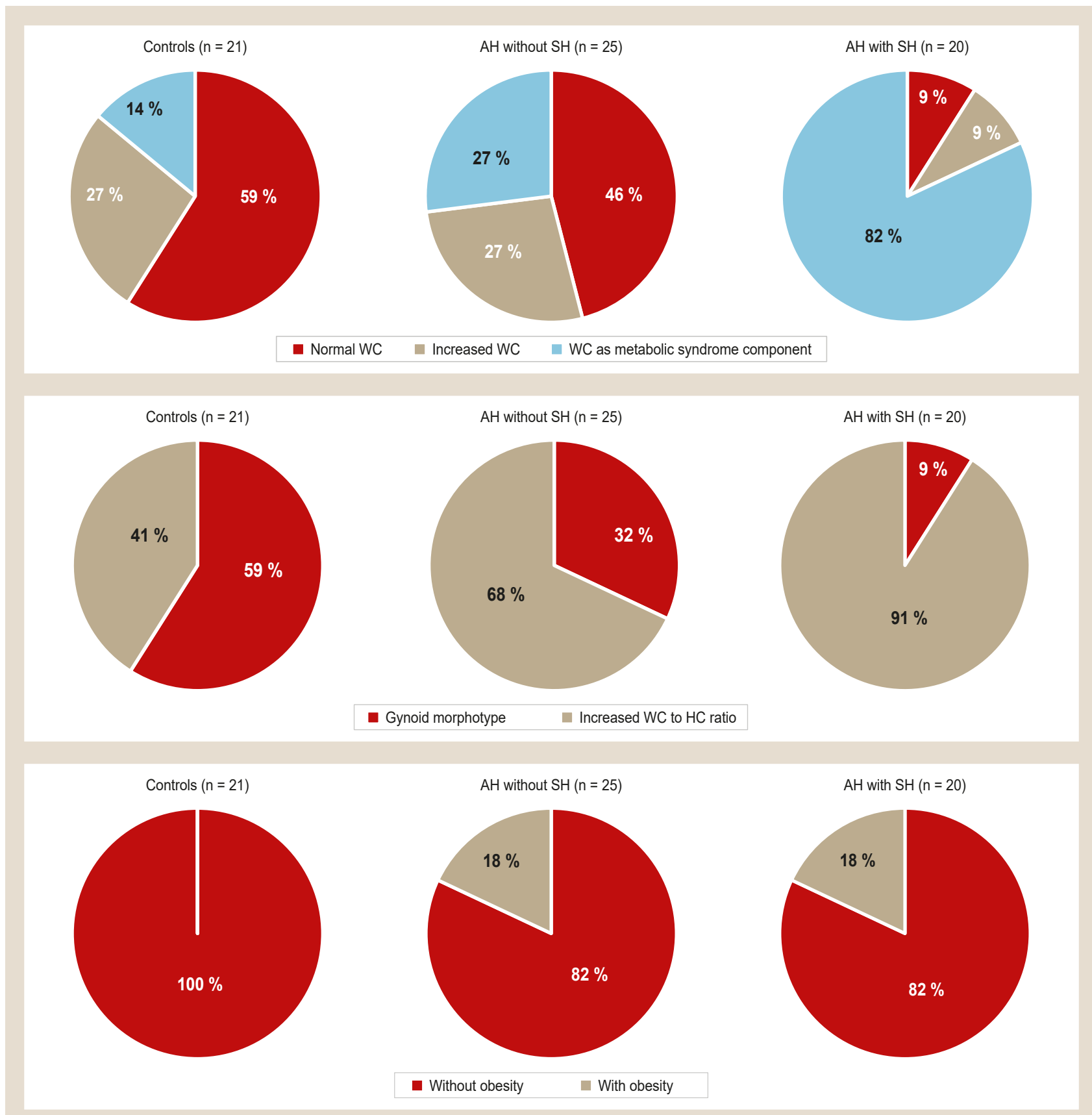

Fig. 2. Prevalence of deviations in selected anthropometric indicators in the studied groups.

Noteworthy statistically significant WC increase and, as a consequence, the better $\mathrm{WC}$ to $\mathrm{HC}$ ratio were seen in group 3 patients compared with group 2 .

Further distribution of the obtained results into groups depending on the values of WC, WC to $\mathrm{HC}$ ratio and BMI revealed an increase in the degree of visceral obesity from the control group to the group of patients with $\mathrm{AH}$ and $\mathrm{SH}$ (Fig. 2). The proportion of individuals with normal WC among patients with $\mathrm{AH}$ and $\mathrm{SH}$ decreased, and the percentage of patients with increased and excessive WC as an obligatory component of MS, increased. In addition, the gynoid morphotype was predominant among controls, while this ratio changed in group 2 , and in group 3 , such a protective profile had only $9 \%$ of patients.
Statistically significant differences were found in the levels of TG, LDL-C and HOMA-IR between the controls and AH patients without $\mathrm{SH}$, and in the levels of HOMA-IR between the controls and $\mathrm{AH}$ patients with SH (Table 2). There was also a tendency for increased levels of glucose, TC, LDL-C, $\mathrm{AC}$ in group 3 patients compared with those in group 2.

Analysis of the MS prevalence, its components, as well as different types of dyslipidemia among patients of different groups (Table 3) showed that the best metabolic profile in terms of CVD prevention was more common in patients with $\mathrm{AH}$ without $\mathrm{SH}$ in comparison to $\mathrm{AH}$ patients with $\mathrm{SH}$. The prevalence of MS was doubled in patients with $\mathrm{SH}$. Notably, in group 3 patients, there was an increase in the frequency of lipid disorders and their combinations 
Table 2. Fasting glucose levels and lipid profile in the studied patients

\begin{tabular}{|c|c|c|c|c|}
\hline Indicators, units & $\begin{array}{l}\text { Controls } \\
(n=21)\end{array}$ & $\begin{array}{l}\text { AH without SH } \\
(n=25)\end{array}$ & $\begin{array}{l}\text { AH with SH } \\
(n=20)\end{array}$ & $\begin{array}{l}\mathbf{P}^{1} \\
\mathbf{P}^{2} \\
\mathbf{P}^{3}\end{array}$ \\
\hline Glucose, $\mathrm{mmol} / \mathrm{l}$ & $5.05[4.87 ; 5.37]$ & $5.27[4.86 ; 5.60]$ & $5.36[4.85 ; 5.74]$ & $\begin{array}{l}0.315 \\
0.320 \\
0.607\end{array}$ \\
\hline HOMA-IR & 2.52 [2.26; 2.97] & $3.92[2.96 ; 6.12]$ & $4.32[2.87 ; 7.25]$ & $\begin{array}{l}0.034 \\
0.021 \\
0.114\end{array}$ \\
\hline $\mathrm{TC}, \mathrm{mmol} / \mathrm{l}$ & $5.08[4.68 ; 5.84]$ & $5.47[4.58 ; 6.11]$ & $6.12[4.37 ; 7.41]$ & $\begin{array}{l}0.460 \\
0.252 \\
0.336\end{array}$ \\
\hline TG, mmol/l & $1.15[0.88 ; 1.37]$ & $1.48[1.12 ; 2.25]$ & $1.17[1.02 ; 1.51]$ & $\begin{array}{l}0.027 \\
0.433 \\
0.266\end{array}$ \\
\hline VLDL-C, mmol// & $0.56[0.39 ; 0.62]$ & $0.67[0.51 ; 1.02]$ & $0.67[0.46 ; 0.72]$ & $\begin{array}{l}0.045 \\
0.181 \\
0.578\end{array}$ \\
\hline $\mathrm{HDL}-\mathrm{C}, \mathrm{mmol} / \mathrm{l}$ & $1.51[1.18 ; 1.67]$ & $1.23[1.08 ; 1.59]$ & $1.31[1.19 ; 1.62]$ & $\begin{array}{l}0.071 \\
0.528 \\
0.343\end{array}$ \\
\hline$A C$ & $2.76[2.07 ; 3.34]$ & $3.12[2.02 ; 4.27]$ & $3.41[2.21 ; 4.40]$ & $\begin{array}{l}0.121 \\
0.214 \\
0.956\end{array}$ \\
\hline LDL-C, mmol/L & $3.13[2.84 ; 3.58]$ & 3.34 [2.59; 4.18] & $4.05[2.28 ; 4.96]$ & $\begin{array}{l}0.307 \\
0.207 \\
0.297\end{array}$ \\
\hline
\end{tabular}

P1: controls vs AH without SH; P2: controls vs $\mathrm{AH}$ with SH; P3: AH without $\mathrm{SH}$ vs $\mathrm{AH}$ with $\mathrm{SH}$.

Table 3. Frequency of metabolic syndrome detection, its components and different types of dyslipidemia in the studied groups

\begin{tabular}{l|l|l|l}
\hline Indicators, units & $\begin{array}{l}\text { Controls } \\
(\mathbf{n}=\mathbf{2 1})\end{array}$ & $\begin{array}{l}\text { AH without SH } \\
(\mathbf{n}=\mathbf{2 5})\end{array}$ & $\begin{array}{l}\text { AH with SH } \\
(\mathbf{n}=\mathbf{2 0})\end{array}$ \\
\hline MS, \% & 0.0 & 9.1 & 18.2 \\
\hline Dyslipidemia, \% & 68.2 & 78.8 & 72.7 \\
\hline Components of MS & & & 18.2 \\
\hline$\uparrow T G+\downarrow H D L-C, \%$ & 0.0 & 12.1 & 9.1 \\
\hline$\uparrow T G+\uparrow g l u c o s e, \%$ & 4.5 & 15.2 & 9.1 \\
\hline$\downarrow H D L-C+\uparrow g l u c o s e, \%$ & 4.5 & 15.2 & 36.4 \\
\hline$\uparrow g l u c o s e, \%$ & 18.2 & 30.3 & 65.0 \\
\hline$\uparrow H O M A-I R, \%$ & 9.0 & 36.0 & 63.6 \\
\hline Types of dyslipidemia & & & 18.2 \\
\hline$\uparrow T C, \%$ & 45.5 & 60.6 & 36.4 \\
\hline$\uparrow T G, \%$ & 4.5 & 36.4 & 63.6 \\
\hline$\downarrow H D L-C, \%$ & 22.7 & 27.3 & 18.2 \\
\hline$\uparrow L D L-C, \%$ & 50.0 & 63.6 & 63.36 \\
\hline$\uparrow T C+\uparrow T G, \%$ & 0.0 & 24.2 & 27.3 \\
\hline$\uparrow T C+\uparrow L D L-C, \%$ & 40.9 & 57.6 & 27.3 \\
\hline$\uparrow T C+\downarrow H D L-C, \%$ & 9.1 & 15.2 & 18.2 \\
\hline$\uparrow L D L-C+\downarrow H D L-C, \%$ & 13.6 & 21.2 & \\
\hline$\uparrow L D L-C+\uparrow V L D L-C+\downarrow H D L-C, \%$ & 0.0 & 9.1 & \\
\hline
\end{tabular}

in addition to the tendency for deterioration of mean lipid values compared with other groups.

\section{Discussion}

Although patients with overt hypothyroidism often complain of weight gain, the association between $\mathrm{SH}$ and weight was less clear, especially in AH patients. Dey A., Kanneganti V., Das D. (2019) found that among SH patients with a mean age of $35.1 \pm 10.26$ years, $12 \%$ were overweight, $24 \%$ were obese, $44 \%$ had a high waist-to-hip ratio, indicating on central obesity, $20 \%$ had high both BMI and waist-to-hip ratio [13]. A significant relationship between central obesity and SH was found by T. M. J. Santhoshakumari, M. Sneha
(2019) [14]. On the other hand, there was an assumption that weight gain contributed to the further development of SH. Zynat J. et al. (2020) found that abdominal obesity was a risk factor for elevated levels of antibodies to thyroid peroxidase in men [15]. The results of another study showed that the average level of TSH increased with increasing BMI [16]. The results of our study indicated a decrease in the severity of constitutional deviation in patients with $\mathrm{AH}$ and concomitant $\mathrm{SH}$. However, we did not evaluate the level of antibodies to thyroperoxidase or antithyroid antibodies in patients. It is interesting, that in patients with $\mathrm{AH}$ and $\mathrm{SH}$, the waist-to-hip ratio was better that in patients without $\mathrm{SH}$. Therefore, there is a need for a more in-depth study of the "safe" limits of $\mathrm{HC}$ in $\mathrm{AH}$ patients with $\mathrm{SH}$. After all, it is impossible to exclude the formation of a specific morphotype in patients with $\mathrm{AH}$ and $\mathrm{SH}$ in order to improve the processes of catabolism and protect the body from excessive accumulation of adipose tissue.

According to C. Xu et al. (2019), the proportion of individuals with high glucose levels in the group of people with $\mathrm{SH}$ was much higher than in controls. The risk of diabetes mellitus was likewise 2.29 times increased among people with SH [17]. In the current study, fasting glucose levels and HOMA-IR were increased, as well as the prevalence of elevated glucose levels and insulin resistance in people with $\mathrm{AH}$ and $\mathrm{SH}$, but these changes were not significant.

The results of the available studies emphasize that $\mathrm{SH}$ patients have higher lipid levels, which may not correspond to the range of dyslipidemias, but contribute to the CVR in patients. Dey A., Kanneganti V., Das D. (2019) found that $92 \%$ of SH patients had dyslipidemia. Among them, there were $36 \%$ of hypertriglyceridemia cases, $36 \%$ - hypercholesterolemia, $32 \%$ - increased LDL-C, $64 \%$ - increased LDL-C, $68 \%$ - reduced HDL-C [13]. Evaluation of our study results revealed the tendency for the lipid profile deterioration and increase in the incidence of dyslipidemia in patients with $\mathrm{AH}$ and $\mathrm{SH}$. The levels of TG and HDL-C were slightly better in patients with $\mathrm{AH}$ and $\mathrm{SH}$ compared to those in group 2, but the differences were not statistically significant. The detected changes may be related to lipid metabolism in the liver and require careful study on the lipid profile changes in patients with $\mathrm{AH}$ and $\mathrm{SH}$ depending on the liver functional status in this category of patients.

In a study of R. Li et al. (2020), a multivariate analysis conducted among patients in China identified $\mathrm{SH}$ as an independent risk factor for the development of MS [18]. Interestingly, the multivariate logistic regression analysis performed by L. Jiang et al. (2020), demonstrated the opposite impact, namely BMI and BP were independent predictors of SH development in women [19]. In our study, the prevalence of MS among patients with $\mathrm{AH}$ and $\mathrm{SH}$ was also higher as compared with patients of other groups.

\section{Conclusions}

1. $\mathrm{HC}$ is statistically increased in patients with $\mathrm{AH}$ and $\mathrm{SH}$ compared with euthyroid $\mathrm{AH}$ patients.

2. In patients with $\mathrm{AH}$ and $\mathrm{SH}$ compared with the group of euthyroid $\mathrm{AH}$ patients, the increase in the values of fasting glucose, TC, LDL-C, AC is seen, while the levels of TG, $\mathrm{HDL}-\mathrm{C}$, on the contrary, tend to improve, although these changes are not statistically significant. 
3. The prevalence of combined lipid profile disorders is higher among patients with $\mathrm{AH}$ and $\mathrm{SH}$ compared with euthyroid AH patients.

4. Metabolic profile is generally deteriorated in patients with $\mathrm{AH}$ even in the early stages and low-to-moderate CVR in combination with $\mathrm{SH}$, that further increases the risk of other CVD and type 2 diabetes mellitus development.

5. Timely detection of $\mathrm{SH}$ in $\mathrm{AH}$ patients and a better monitoring of anthropometric parameters and the lipid and carbohydrate profile indices are necessary in order to prevent complications.

Prospects for further research are to study the relationship between inflammatory markers, oxidative stress indicators and cardiometabolic parameters in $\mathrm{AH}$ patients depending on thyroid dysfunction.

Conflicts of interest: authors have no conflict of interest to declare. Конфлікт інтересів: віАсутній.

Надійшла Ао редакції / Received: 27.05.2021

Після Аоопрацювання / Revised: 14.06.2021

Прийнято Ао Аруку / Accepted: 01.07.2021

\section{Information about authors:}

Radchenko A. O., MD, PhD-student of the Department of Study of Aging Processes and Prevention of Metabolic-Associated Diseases, GI “L. T. Malaya Therapy National Institute of the National Academy of Medical Sciences of Ukraine", Kharkiv. ORCID ID: 0000-0002-9687-8218

Kolesnikova O. V., MD, PhD, DSc, Professor, Deputy Director for Scientific Work, Head of the Department of Study of Aging Processes and Prevention of Metabolic-Associated Diseases, GI “L. T. Malaya Therapy National Institute of the National Academy of Medical Sciences of Ukraine", Kharkiv. ORCID ID: 0000-0001-5606-6621

\section{Відомості про авторів:}

Радченко А. О., PhD-аспірант віАділу вивчення процесів старіння і профікактики метаболічно асоційованих захворювань, АУ „Національний інститут терапії імені ^. Т. Малої НАМН України", м. Харків.

Колеснікова О. В., А-р меА. наук, професор, заст. Аиректора 3 наукової роботи, зав. віАділу вивчення процесів старіння і профікактики метаболічно асоційованих захворювань, АУ «Національний інститут терапії імені $А$. Т. Малої НАМН України", м. Харків.

\section{Сведения об авторах:}

Радченко А. О., PhD-аспирант отАела изучения процессов старения и профилактики метаболически ассоциированных заболеваний, ГУ «Национальный институт терапии имени ^. Т. Малой НАМН Украины", г. Харьков.

Колесникова Е. В., А-р меА. наук, профессор, зам. Аиректора по научной работе, зав. отАелом изучения процессов старения и профилактики метаболически ассоциированных заболеваний, ГУ «Национальный институт терапии имени $\Lambda$. Т. Малой НАМН Украины", г. Харьков.

\section{References}

[1] Wilkins, E., Wilson, L., Wickramasinghe, K., Bhatnagar, P., Leal, J., Luengo-Fernandez, R., Burns, R., Rayner, M., \& Townsend, N. (2017). European Cardiovascular Disease Statistics 2017 edition. European Heart Network, Brussels. http://www.ehnheart.org/images/CVD-statistics-report-August-2017.pdf

[2] (2020). Corrigendum to: European Society of Cardiology: Cardiovascular Disease Statistics 2019. European Heart Journal, 41(47), 4507. https://doi.org/10.1093/eurheartj/ehaa062

[3] Stanaway, J. D., Afshin, A., Gakidou, E., Lim, S. S., Abate, D., Abate, K. H., Abbafati, C., Abbasi, N., Abbastabar, H., Abd-Allah, F.,
Abdela, J., Abdelalim, A., Abdollahpour, I.,Abdulkader, R. S., Abebe, M. Abebe, Z., Abera, S. F., Abil, O. Z., Abraha, H. N., \& Abrham, A. R. (2018). Global, regional, and national comparative risk assessment of 84 behavioural, environmental and occupational, and metabolic risks or clusters of risks for 195 countries and territories, 1990-2017: a systematic analysis for the Global Burden of Disease Study 2017 The Lancet, 392(10159), 1923-1994. https://doi.org/10.1016/s0140$\underline{6736(18) 32225-6}$

[4] Nair, S. N., Kumar, H., Raveendran, M., \& Menon, V. U. (2018). Subclinical Hypothyroidism and Cardiac Risk: Lessons from a South Indian Population Study. Indian Journal of Endocrinology and Metabolism, 22(2), 217-222. https://doi.org/10.4103/ijem.IJEM $298 \quad 17$

[5] Piantanida, E., Gallo, D. Veronesi, G., Pariani, N., Masiello, E., Premoli, P., Sassi, L., Lai, A., Tanda, M. L., Ferrario, M., \& Bartalena, L. (2016). Masked hypertension in newly diagnosed hypothyroidism: a pilot study. Journal of Endocrinological Investigation, 39(10), 1131-1138. https:/l doi.org/10.1007/s40618-016-0488-7

[6] Delitala, A. P., Scuteri, A., Maioli, M., Mangatia, P., Vilardi, L., \& Erre, G. L. (2019). Subclinical hypothyroidism and cardiovascular risk factors. Minerva Medica, 110(6), 530-545. https://doi.org/10.23736/ S0026-4806.19.06292-X

[7] Zaprovalna, O. Ye., Kolesnikova, O. V., Radchenko, A. O., Bondar, T. M., \& Potapenko, A. V. (2021). Pokaznyky peredchasnoho starinnia u patsiientiv iz pomirnym kardiovaskuliarnym ryzykom [Premature aging indices in patients with moderate cardiovascular risk]. Mizhnarodnyi medychnyi zhurnal, 27(1), 5-9. https://doi.org/10.37436/23085274-2021-1-1 [in Ukrainian].

[8] Inoue, K., Ritz, B., Brent, G. A., Ebrahimi, R., Rhee, C. M., \& Leung, A. M. (2020). Association of Subclinical Hypothyroidism and Cardiovascular Disease With Mortality. JAMA Network Open, 3(2), Article e1920745. https://doi.org/10.1001/jamanetworkopen.2019.20745

[9] Manolis, A. A., Manolis, T. A., Melita, H., \& Manolis, A. S. (2020). Subclinical thyroid dysfunction and cardiovascular consequences: An alarming wake-up call? Trends in Cardiovascular Medicine, 30(2), 57-69. https://doi.org/10.1016/j.tcm.2019.02.011

[10] He, W., Li, S., Wang, B., Mu, K., Shao, X., Yao, Q., Li, L., Li, Q., \& Zhang, J. A. (2019). Dose-response relationship between thyroid stimulating hormone and hypertension risk in euthyroid individuals. Journal of Hypertension, 37(1), 144-153. https://doi.org/10.1097/ HJH.0000000000001826

[11] Korevaar, T. I. M. (2016). Thyroid-Function Changes Within the Normal Range Are a Risk Factor for Type 2 Diabetes Mellitus. Clinical Thyroidology, 28(12), 379-381. https://doi.org/10.1089/ct.2016:28.379-381

[12] Chang, Y. C., Hua, S. C., Chang, C. H., Kao, W. Y., Lee, H. L., Chuang, L. M., Huang, Y. T., \& Lai, M. S. (2019). High TSH Level within Normal Range Is Associated with Obesity, Dyslipidemia, Hypertension, Inflammation, Hypercoagulability, and the Metabolic Syndrome: ANovel Cardiometabolic Marker. Journal of Clinical Medicine, 8(6), Article 817. https://doi.org/10.3390/icm8060817

[13] Dey, A., Kanneganti, V., \& Das, D. (2019). A study of the cardiac risk factors emerging out of subclinical hypothyroidism. Journal of Family Medicine and Primary Care, 8(7), 2439-2444. https://doi.org/10.4103/ ifmpc.jfmpc $348 \quad 19$

[14] Santhoshakumari, T. M. J., \& Sneha, M. (2019). Association between abdominal obesity and subclinical hypothyroidism. Biomedical Research, 30(5), 760-763. https://doi.org/10.35841/biomedicalresearch.30-19-294

[15] Zynat, J., Li, S., Ma, Y., Han, L., Ma, F., Zhang, Y., Xing, B., Wang, X. \& Guo, Y. (2020). Impact of Abdominal Obesity on Thyroid Auto-Antibody Positivity: Abdominal Obesity Can Enhance the Risk of Thyroid Autoimmunity in Men. International Journal of Endocrinology, 2020, Article 6816198. https://doi.org/10.1155/2020/6816198

[16] Baral, B. R., Koirala, M., Lamichhane, B. S., Paudel, S. R., Banstola, L., Nepal, A., \& Sharma, S. (2019). Correlation of serum thyroid stimulating hormone with body mass index in healthy adults. Medical Journal of Pokhara Academy of Health Sciences, 2(1), 116-120. https://doi. org/10.3126/mipahs.v2i3.26104

[17] Xu, C., Zhou, L., Wu, K., Li, Y., Xu, J., Jiang, D., \& Gao, L. (2019). Abnormal Glucose Metabolism and Insulin Resistance Are Induced via the IRE1a/XBP-1 Pathway in Subclinical Hypothyroidism. Frontiers in Endocrinology, 10, Article 303. https://doi.org/10.3389/ fendo.2019.00303

[18] Li, R. C., Zhang, L., Luo, H., Lei, Y., Zeng, L., Zhu, J., \& Tang, H. (2020). Subclinical hypothyroidism and anxiety may contribute to metabolic syndrome in Sichuan of China: a hospital-based population study. Scientific Reports, 10(1), Article 2261. https://doi.org/10.1038/s41598020-58973-W

[19] Jiang, L., Du, J., Wu, W., Fang, J., Wang, J., \& Ding, J. (2020). Sex differences in subclinical hypothyroidism and associations with metabolic risk factors: a health examination-based study in mainland China. BMC Endocrine Disorders, 20(1), Article 100. https://doi.org/10.1186 $\underline{\text { s12902-020-00586-5 }}$ 